\title{
Murder: A Critical Analysis of the Common Law Definition
}

\author{
Mohammad Belayet Hossain, Saida Talukder Rahi \\ School of Law, Chittagong Independent University of Bangladesh (CIUB), Chittagong, Bangladesh \\ Email: hasan1215@yahoo.com,galib@ciu.edu.bd
}

How to cite this paper: Hossain, M. B., \& Rahi, S. T. (2018). Murder: A Critical Analysis of the Common Law Definition. Beijing Law Review, 9, 460-480. https://doi.org/10.4236/blr.2018.93028

Received: April 24, 2018

Accepted: September 18, 2018

Published: September 21, 2018

Copyright $\odot 2018$ by authors and Scientific Research Publishing Inc. This work is licensed under the Creative Commons Attribution International License (CC BY 4.0).

http://creativecommons.org/licenses/by/4.0/

(c) (i) Open Access

\begin{abstract}
English Criminal law provides a range of offences that recognizes the sanctity of life by prohibiting the unlawful killing of a human being. The generic term "homicide" covers offences such as murder, manslaughter and causing death by dangerous driving. What all homicides have in common is the unlawful killing of a human being; what distinguishes them is either the state of mind of the defendant who has caused death, or the defense available. This article shall critically analyze the common law definition of murder in various criminal homicide cases to find out if any concrete common law definition could be established. It will be seen throughout this article that though criminal law throws up many exceptions to this general proportion, there is no fixed common law definition of murder. This article shall prompt the question whether the legislature should rethink the forms of criminal homicide and the judiciary reconsiders some of the definitions of the mens rea words produced in recent years.
\end{abstract}

\section{Keywords}

Murder, Actus Reus, Mens Rea, Causation, Homicide

\section{Introduction}

There is no offence of "homicide" as such. A person cannot be charged with or convicted of "homicide". Homicide means the killing of a human being and may be lawful-where, for example, fatal force was necessary to defend oneself. The two most important offences of unlawful homicide are murder and manslaughter (Allen et al. 2001). Although both are common law offences, elements of murder and manslaughter have been modified by Acts of Parliament of UK and the penalties for each are statutory. 
Nevertheless crimes of homicide, and especially murder, are regarded as the most serious and abhorrent crimes. The taking of life and the impact that it can have on the family and friend of the victim give a special significance to offences involving the killing of another human being. The seriousness with which they are regarded is reflected in the maximum penalties. In the case of murder, the Murder (Abolition of Death Penalty) Act 1965 stipulates a mandatory sentence. The judge has no option but to sentence the person convicted of murder to a term of imprisonment for life. Section 269 of the Criminal Justice Act 2003 requires the trial judge to state the minimum term that the convicted murderer should serve before he or she is eligible to be released on license. This should reflect the seriousness of the murder and should be set by reference to one of three starting points: whole life, 30 years and 15 years.

\section{Definition of Murder}

Murder, one of the most serious crimes that can be committed against individuals, has been variously defined:

Hawkins defines it to be "the willful killing of any subject whatever, with malice aforethought, whether the person slain shall be an Englishman or a foreigner" (Ashworth, 2006).

Russell says, "murder is the killing of any person under the king's peace, with malice prepense or aforethought, either express or implied by law" (Card, 2006).

Sir Edward Coke defines or rather describes this offence to be, "when a man of sound memory, and of the age of discretion, unlawfully killeth within any country of the realm any reasonable creature in return nutra under the kings pace, with malice afore thought, either expressed by the party or implied by law (so, as the party wounded, or hurt, etc die of the wound or hurt, etc within a year and day after the same) $)^{2}$."

These classic definition, which has been adopted by others has been severely and perhaps justly criticised. In simple word, murder is the unlawful killing of a human being by a human being during the "Queen's peace" with malice afore thought. Surprisingly enough, despite being the most serious crime (apart perhaps from treason), the offence has not been defined by statute. The present law of murder is a product of judge made law supplemented by parliament's sporadic intervention.

The definition can be broken down into two aspects: actus reus and mens rea. The latin maxim actus non facitreum, nisi mens sit rea means that the act itself does not constitute guilt unless it was done with a guilty mind. Another way of saying this is that criminal liability requires BOTH wrongdoing and culpability or blameworthiness. This is, in fact, not a completely accurate description of the criminal law, as many crimes do not require mens rea, i.e. blameworthiness. Where mens rea is not required liability is termed "strict".

${ }^{1}$ Co Inst Pt III, Ch 7, p. 47.

${ }^{2}$ Ibid. 3 Ins 47 . As to the words in parentheses. 


\subsection{Actus Reus}

This is the "external" element of a crime-i.e. some form of measurable wrongdoing. It comprises the actor's conduct, together with any circumstances, which make that conduct wrongful, and in the case of a result crime, the consequences'. Generally, the actus reus raises the following questions to be answered:

* Who can commit murder?

* Where murder can be committed?

* Who can be the victim?

* Is there any time limit (a year and a day rule)?

* Is it an unlawful act?

* Did the act (by the defendant) cause death of the victim?

\subsection{Mens Rea}

This is the "internal" or mental element of a crime (Duff \& Green, 2005). It must be proved that at the time the defendant was responsible for the actus reus of the offence with which he is charged, he behaved with the state of mind relevant to that offence. So to be guilty of theft he must be proved to be dishonest and intend to keep the property. Where the offence is one which requires proof of mens rea, both elements must be proved in order to secure a conviction. Generally, the mens rea raises the following questions to be answered:

* Malice aforethought or the fault element?

* Did the defendant intent to kill the victim (express malice)?

* Did the defendant intent to cause grievous bodily harm to the victim (implied malice)?

\section{Actus Reus of Murder}

\subsection{Commission of Murder}

"A man of sound memory and of the age of discretion" simply refers to a person, over the age of nine, responsible for killing according to the general principles mentioned above. If the killing was committed before 30 September 1998 by a person who was then under 14, he must be proved to have had a "mischievous discretion"3. The other limitations those must be considered are that the person committed the offence is not insane within the M'Naghten Rules, and since $1957^{4}$, he does not suffer from diminished responsibility. Since, law only allows capital punishment and/or life imprisonment as penalty; a corporation cannot be tried for murder (Clarkson, 2005).

\subsection{Place of Occurrence}

The phrase "Queen's peace" is a strange one as it seems that everyone in the world is under the Queen's or King's peace, except an enemy alien who is killed in the course of war. If an enemy alien is a prisoner of the war he is under the

${ }^{3}$ The Crime and Disorder Act 1998, s. 35 abolished the doliincapax rules from the date. ${ }^{4}$ See section 2 of the Homicide Act 1957. 
Queen's peace. The killing by a British Citizen need not take place within, "any county of the realm". Murder and Manslaughter are exceptional in that English Courts try a British citizen for these offences if committed in any country by s. 9 of the Offences against the Person Act 1861 and s. 3 of the British Nationality Act 1948 (Clarkson \& Keating, 2003). If the offence takes place on a British ship or aircraft it can be tried here whether the perpetrator is a British subject or an alien, but English Court has no jurisdiction if the offence occurs on a foreign ship outside territorial waters. Other statutory extensions are available under which murder may be tried in England and Wales irrespective of the killer's nationality.

\subsection{The Victim Being Identified}

In Coke's famous definition of murder he refers to the killing of a "reasonable creature in rerumnatura" that is simply the "person" who is the victim of an offence-that is "any human being". The burning questions are at what stage of the process of birth a fetus becomes a person; and what stages in the process of death a person becomes a corpse. Article 2 of the European Commission of Human Rights (ECHR) imposes on the state certain obligation to protect life and investigates the taking of life, but the European Court has tried to escape the issue of when life begins and ends (Emmerson \& Ashworth, 2012).

Broadly, Coke's definition seeks to distinguish the killing of human beings from the killing of other creatures, but it clearly provides no guidance as to how this distinction is to be made. For the purpose of homicide, therefore, a human being comes into existence at the moment of birth, provided the child has had an existence independent of its mother. Such independent existence need only be momentary. There are some old authorities on the point, although they may need to be treated with caution, which suggest that whilst the child's body must have been expelled from the mother's womb $(R v \text { Poulton })^{5}$, the cord between mother and child does not have to have been cut $\left(R_{V} \text { Reevs }\right)^{6}$. In $R V$ Brain, Parke $J$ directed the jury that a baby could be the victim of homicide, even though it had not started breathing. Further application of this principle is found in $R_{V}$ Enoch $^{7}$ and $R_{V}$ Handley $^{8}$.

\section{Case Study}

In Re A (Children) (conjoined Twins: Surgical Separation) $)^{9}$ one of the issues before the court was whether the severance of conjoined twins " $J$ " and "M", causing as it would the inevitable death of $\mathrm{M}$, would amount to murder. In particular, there was the issue of whether $\mathrm{M}$, who was entirely dependant upon J for her existence, should be classified as a "reasonable creature" for the purpose of homicide. Rejecting any notion that $\mathrm{M}$ should not be protected by the law, Brooke 
LJ observed that, although $M$ had, "for all practical purposes a useless brain, a useless heart and useless lungs", she will still "alive". He went on to endorse the view that advances in medical treatment of deformed neonates suggested that the criminal law's protection would only be denied in the most extreme cases. To emphasis the point he posed the problem of an intruder entering the hospital where $\mathrm{M}$ was being cared for and stabbing her to death. His view was that such actions would clearly have fallen within the scope of homicide (Douglas, 2005).

Regarding the point at which life ceases for the purposes of homicide, doctors frequently refer to a patient as being "brain dead", indicating that, whilst he can be kept alive on a life support machine, there is no chance of his ever-recovering consciousness. For the purposes of criminal law such a patient would not be regarded as "legally dead", in the sense that if defendant were to enter a hospital ward and deliberately switch off a machine maintaining the vital functions of such a patient, he could still nevertheless be charged with murder or manslaughter kept alive on a life support machine, there is no chance of his ever recovering consciousness.

\subsection{Act Must Be Unlawful}

"Whether killing is unlawful" is an important issue of the offence. Self-defence is the most obvious example of its application. The court to protect others has applied this element. It was accepted by the Court of Appeal in the Attorney-General's Reference (No 3 of 1994) ${ }^{10}$ that no liability of murder would be found against the doctor who performed a lawful abortion, had the fetus be born alive and die because of injuries sustained in the abortion procedure. According to the Abortion Act 1967, in such a case, the doctor would not have performed an unlawful act. Though, consent in many offences renders conduct lawful, cannot be used as a defence in the context of $\operatorname{murder}^{11}$ (Molan, 2007).

\subsection{Time Limitation}

Coke's classic definition of murder included a requirement that the victim's death had to occur within a year and a day. Even until 1996 victim's death within a year and a day (366 days) of the defendant's act was the common law requirement. Hence, at common law, by virtue of what was known as the "year and a day rule", defendant (D) would not have been guilty of either murder or manslaughter if Victim (V) had died more than 366 days from the date upon which $\mathrm{D}$ inflicted harm upon $\mathrm{V}$. The basis for this rule, the origin of which could be traced back over 800 years, was that if $\mathrm{V}$ had survived for more than a year after being attacked by $\mathrm{D}$ there would be great uncertainty, if $\mathrm{V}$ subsequently died, as to whether D's act was the cause of death or other supervening cause was responsible. For comparatively resent illustrations of the rule being applied in $R V$ $D_{y s o n}{ }^{12}$ (Martin, 2006) and $R v$ Coroner for Inner West London, ex parte De ${ }^{10}[1993] 1$ AC 789.

${ }^{11}$ See R v Buck and Buck, 44 Cr App R 213; R v Creamer [1966] 1 QB 72.

${ }^{12}[1908] 2$ KB 454. 
Luca $^{13}$. It was open to the courts to convict D of a non fatal offence, such as grievous bodily harm with intent and, if V died without 366 days of D's attack charge D with murder or manslaughter at his first trial ${ }^{14}$ (Herring, 2007).

Unsuccessful attempts were made to introduce an amendment to what became the Criminal Justice and Public Order Act 1994when it was before the House of Commons so as to include a clause abolishing the year and a day rule, proponents of change pointing out that in this respect English Law was out of step with that of other comparable countries, the rule never having been part of Scots Law, and no longer forming part of the law in any European country other than Cyprus. The argument that the rule was needed because of the evidential difficulty in determining whether D's act caused V's death no longer bore close scrutiny, given the state of modern forensic science. Particularly difficult moral and ethical questions arose where the victim of a criminal attack was left in a persistent vegetative state as a result of injuries inflicted by D. Given the technical ability to sustain patients in this condition for many years, it was seen as absurd that D should escape liability for murder or manslaughter simply because the decision to discontent a life support system was effected more than 366 days after his unlawful act. The rule was also open to criticism on the ground that it presented problems to prosecutors considering manslaughter charges against companies where unsafe working practices resulted in the deaths of employees some years after being exposed to health dangers in the workplace.

In its report Legislating the Criminal Code: The "Year and a Day Rule" in Homicide $^{15}$, the Law Commission recommended the abolition of the rule, and these proposals have since been enacted, with some amendments, in the form of the Law Reform (Year and a Day Rule) Act 1996. Under the 1996 Act, which has the effect of abolishing the year and a day rule, there are two situations where the Attorney-General's consent will be required if any person is to be prosecuted for a "fatal offence". The first is where the death of the victim occurs more than three years after the injury alleged to have caused the death is sustained, and the second is where the person to be prosecuted has already been convicted of an offence committed in connection with the offence. The Act, which applies in England, Wales and Northern Ireland, came into effect on 17 August 1996.

\subsection{Causing Death of the Victim by the Defendant}

Murder is a result crime in the sense that the defendant must be proved to have caused the victim's death. Two matters have to be considered:

- Whether the defendant in fact cause the victim's death;

- And if so, whether the defendant had any lawful excuse of causing death of the victim.

\footnotetext{
${ }^{13}$ [1988] 3 WLR 286.

${ }^{14} \mathrm{R} v$ Golding (1994) The times 28 April.

${ }^{15}$ Homicide Consultation Paper No. 136, 1994.
} 


\section{Consideration of Aspects of Causation}

\subsection{Causation in Fact}

Factual causation is determined by reference to the sine quo non (or "but for") test. It is a precondition of proof of causation but is not sufficient, in itself, to determine the casual link. Nonetheless the defendant's conduct must actually be demonstrated to have been the sine qua non of the result. Whether something amounts to a factual cause of an event is a question of fact for the jury, who will determine this by reference to the "but for" test. If the result would have occurred regardless of the defendant's conduct, then he cannot be said to have caused that result regardless of his intention. The "but for" test is the starting point for the consideration of causation but will never, of itself, determine the outcome ${ }^{16}$.

\section{Case Studies}

The case of $R V$ White $^{17}$ illustrates how problems can arise. The defendant placed two grains of potassium cyanide in a glass containing his mother's drink. She drank the contents of the glass, but died of heart failure before the poison could take effect. The defendant was charged with murder, and, convicted of attempted murder, a finding against which he appealed unsuccessfully. As regards causation of fact, the defendant's act in placing the poison in his mother's drink did not in any way cause her death. If one were to ask, "But for the defendant's act would his mother have died? The answer would obviously have to be in the affirmative; she would have died anyway, thus disproving causation in fact. In such cases the appropriate charge would then be one of attempting to commit the substantive offence, provided that the defendant has taken sufficient steps towards its commission (Keenan, 2007).

Another example where causation in fact is not self-evident is the case of $R \mathrm{~V}$ Cannings $^{18}$. The defendant was the mother of four children, three of whom died in infancy. She was charged with the mother of four children, three of whom died in infancy. She was charged with the murder of two of her sons and a charge of murder of her first child was not proceeded with. At the trial the crown adduced evidence that the three children who died had suffered an acute life-threatening event. It was alleged by the Crown that the mother had smothered her children intending to kill them or do them really serious bodily harm by obstructing their breathing. The defendant had denied harming her children and it was her case that the deaths were natural, if unexplained, incidents to be classified as sudden infant death syndrome. Experts called by the Crown and the defendant failed to agree and the defendant was convicted of murdering her sons.

Allowing the appeal and quashing the convictions, the Court of Appeal held

\footnotetext{
${ }^{16}$ Carey (2006) EWCACrim 17.

${ }^{17}[1910] 2 \mathrm{~KB} 124$.

${ }^{18}$ [2004] EWCACrim 1.
} 
that where there was one, two or even three infant deaths in the same family the exclusion currently unknown natural cause of infant death did not lead to the inexorable conclusion that the deaths resulted from the deliberate infliction of harm. The Court further held that where there was serious disagreement between reputable exclude as a reasonable possibility, the prosecution of a parent for murder should not be shared.

\subsection{Causation in Law}

Simply because a chain of causation in fact can be established, it should not be assumed that legal liability will follow. The principles of causation in law exist to prevent $\mathrm{D}$ from being convicted where his acts are too remote from the death, or where his acts are only a minimal cause of death. The general test to be applied in order to establish causation in law is whether D's act has accelerated V's death to an extent that is more than merely negligible? D's act does not necessarily need to be a substantial cause of V's death, but must be more than de minimis. Assuming that, prima facie, D's act is a cause in law of V's death, D may be able to contend that there has been a novus actus interveniens, or break in the chain of causation, that relieves him of liability for the completed offence.

\subsubsection{Novus Actus Interveniens: The Act and Omissions of the Victim}

The duty resting upon the victim to mitigate the harmful effects of any wrongful action is a well-developed concept in the law of Torts, there appears to be no corresponding duty resting upon the victim of an unlawful criminal assault. Hence, if $\mathrm{D}$ attacks $\mathrm{V}$, causing injuries that is potentially life threatening, and $\mathrm{V}$ neglects to attend to the injuries or seek competent assistance, with the result that $\mathrm{V}$ dies, $\mathrm{D}$ may be unable to contend that V's failure to obtain medical treatment broke the chain of causation.

\section{Case Studies}

In $R V_{V}$ Holland $^{19}$, D struck V's hand with an iron bar, causing it to be badly cut. $\mathrm{V}$ decided not to seek treatment, developed lockjaw, and later died. The court held that $\mathrm{D}$ had caused the death of $\mathrm{V}$ in fact and in law. Same decision was taken by the court in $R{ }_{V} W^{2} l^{2}$. Whilst this decisions might seems justifiable given the somewhat crude state of medical treatment at the time, the principle is still applicable today, the leading modern authority being the decision of the Court of appeal in $R v$ Blaue $^{21}$. D had stabbed $\mathrm{V}$ who was a Jehovah's Witness, and she was admitted to hospital where doctors diagnosed that she would need an immediate blood transfusion if her life were to be saved. $V$ refused the necessary transfusion, because it was against her religious beliefs, and died of her wounds shortly after. D appealed against his conviction for manslaughter on the ground that V's refusal of treatment had broken the chain of causation, but the court held that he had to take his victim as he found her, meaning not just her 
physical condition but also her religious belief. In a sense what the court was doing in this case was extending the so-called "thin skull rule" to encompass not just the physical peculiarities of the victim but also the victim's mental state. As Lawton LJ observed:

"It has long been the policy of the law that those who use violence on other people must take their victims as they find them. This in our judgment means the whole man, not just the physical man. It does not lie in the mouth of the assailant to say that his victim's religious beliefs which inhibited him from accepting certain kinds of treatment were unreasonable."

Whilst Blaue suggests that no peculiarities of $\mathrm{V}$ can be relied upon by $\mathrm{D}$ to contend that the chain of causation was broken by V's action or inaction a slightly different analysis emerges from those cases dealing with so-called "escape" situations: those where V dies in his or her efforts to escape from an attack threatened or perpetrated by D. Early cases on this point establish that such a defendant can be charged with murder or manslaughter, provided that V's fear was well grounded ${ }^{22}$ (Holland \& Webb, 2006).

More recently, in $R V M_{a k i e^{23}}$, the Court of Appeal upheld the manslaughter conviction of $\mathrm{D}$ whose three-year-old son fell downstairs and died in trying to escape from a beating, the court endorsing the trial judge's direction to the jury which had invited them to consider, first, whether the boy had been in fear, secondly whether that fear had caused him to try to escape, thirdly whether the fear was well founded, and if so, whether that fear had caused him to try to escape, thirdly whether the fear was well founded, and if so, whether it was caused by the unlawful conduct of $\mathrm{D}$.

In $D P P_{V}$ Dale $^{24}$, Lord Keith summarized what, in their Lordships' view, the prosecution had to establish in such cases, namely the following:

- V, immediately before he sustained his injuries, was in fear of being hurt physically;

- V's fear was such that it caused him to try to escape;

- Whilst $\mathrm{V}$ was trying to escape, and because he was trying to escape, he met his death;

- V's fear of being hurt there and then was reasonable and was caused by the conduct of D;

- D's conduct which caused the fear was unlawful;

- D's conduct was such as any sober and reasonable person would recognize as likely to subject the victim to at least the risk of some harm resulting from it, albeit not serious harm (Roe, 2005).

In spite of the detailed nature of these guidelines, it may still be necessary, in some cases, to give a jury further guidance on the issue of causation, particularly where there is evidence that P's reaction was disproportionate to D's threat. In $R$

\footnotetext{
${ }^{22} \mathrm{R}$ v Pitts (1842) Car \& M 248.

${ }^{23}(1973) 57$ Cr App R 453.

${ }^{24}(1980)$ AC 237.
} 
${ }_{V}$ Roberts ${ }^{25}$ Stephenson LJ suggested that the correct approach is to ask:

"Was [the victim's reaction] the natural result of what the assailant said and did, in the sense that it was something that could reasonably have been foreseen as the consequence of what he was saying or doing? As it was said in one of the old cases, it had got to be shown to be his act, and if of course the victim does something so "daft", in the words of the appellant in this case, or so unexpected, [such]... that this particular assailant did not actually foresee it [and]... that no reasonable man could be expected to foresee it, then it is only in a very remote and unreal sense a consequence of his assault, it is really occasioned by a voluntary act on the part of the victim which could not be reasonably foreseen and which breaks the chain of causation between the assault and the harm or injury."

In short, if V's response to D's threats is reasonably foreseeable, it will not constitute a novus actus interveniens $\left[R_{V} \text { Corbett }\right]^{26}$. The test for reasonable foreseeability is objective-would a reasonable person have foreseen V's action? Though in $R V$ Williams $^{27}$ the court referred to the test being based on the reasonable person "in the assailant's shoes", $R v$ Majoram $^{28}$ makes clear that for these purposes the reasonable person does not share any of D's personal attributes. The reasonable person is simply in the same circumstances as D-this presumably means at the scene of the crime. It may be concluded that that an unforeseeable or "draft" action by V, by way of response to D's threats or attack, may result in the chain of causation being broken.

In $R v$ Dear $^{29}$, D was convicted of murder of $\mathrm{V}$, having attacked $\mathrm{V}$ and stabbed him several times with a knife. D appealed on the basis that $\mathrm{V}$ had effectively committed suicide, thus broken the chain of causation in law, either by reporting wounds inflicted by D, or by failing to seek medical attention for wounds inflicted by $\mathrm{D}$ that had subsequently reopened of their own accord. Dismissing the appeal, the court of appeal took the view that $\mathrm{V}$ had died of wounds inflicted by $\mathrm{D}$, and that D's liability should not depend on distinction between V's acting negligently or with gross negligence in respect of his injuries. A jury would be entitled to find that D's stabbing of V was a cause in law of V's death even if V had deliberately reopened the wounds. On the basis that the wounds inflicted by $\mathrm{D}$ were an operating and substantial cause of death, the decision is uncontroversial, indeed, unremarkable. The decision does, however, raise questions as to the limits of liability. If V's wounds were well on the way to being healed and he chose, for whatever reason, to pick at them, causing them to reopen, with fatal consequences, would D still be regarded as having caused the death? At what point such activity fall outside the scheme of foreseeable actions referred to in Roberts, and become "daft"? Alternatively, does D, on the basis of Blaue, have to take the victim as he finds him, including his "daft" behaviour in respect of his

\footnotetext{
${ }^{25}$ (1971) 56 Cr App R 95.

${ }^{26}(1996)$ CrimLR 594.

${ }^{27}$ (1992) 1 WLR 380.

${ }^{28}$ (2000) CrimLR 372.

${ }^{29}$ (1996) CrimLR 595.
} 
injuries? The solution might lie in distinguishing between cases where the original injury inflicted by D is the cause of death, and those in which D's unlawful acts are merely the background explaining why $\mathrm{V}$ took action that amounted to an independent and supervening cause of death. The issue has arisen in a number of cases involving the supply of drugs by $\mathrm{D}$ and the voluntary consumption of the drugs, with fatal consequences, by V. In $R v D a l b y^{30}$ the Court of Appeal allowed D's appeal against his conviction for manslaughter based on these facts on the basis, as Waller LJ observed, that:

"In this case the supply of drugs would itself have caused no harm unless the deceased had subsequently used the drugs in a form and quantity which was dangerous."

This suggests that V's voluntary act in consuming the drugs was an independent and operating cause of death, a view subsequently confirmed in $R v$ Goodfellow ${ }^{31}$.

In $R$ Armstrong $^{32}$, a drug addict, supplied $\mathrm{V}$, who had already taken large amount of alcohol, with heroin and drug-taking paraphernalia. $\mathrm{V}$ died shortly after self-injection of a large quantity of the heroin. The court upheld defence counsel's submissions that either there was, on the facts, no or no sufficient evidence that heroin had been a substantial cause of death, or alternatively that if heroin did cause death; V's self-injection was a novus actus interveniens.

It is submitted that Dalby and Armstrong are decisions that mark the point at which the defendant, which no longer responsible for the actions of the victim, a view further supported by the more recent decision in $R_{V}$ Dias $^{33}$. In that case $\mathrm{D}$ purchased heroin with $\mathrm{V}$ and prepared the syringe that $\mathrm{V}$ used to inject himself with the solution. $\mathrm{V}$ died shortly afterwards from the resulting overdose. Hence $\mathrm{D}$ is encouraging $\mathrm{V}$ to undertake an activity that carries with it a risk of death, $\mathrm{D}$ cannot be said to be assisting or encouraging an unlawful act by V. Provides V is a sane adult exercising free will, the decision to take the risk is his and his alone. On this basis, for example, where $\mathrm{V}$, having been indecently assaulted by $\mathrm{D}$, commits suicide by shooting himself in the head because of an overwhelming sense of shame or depression, it is submitted that V's action should be regarded as a novus actus interveniens, notwithstanding the ratio of Blaue. The matter has been examined by the civil courts in Pigency $v$ Pointers Transport Services ${ }^{34}$, where it was held that the chain of causation was not broken by V's suicide which was included by an anxiety neurosis developed following an accident caused by D's negligence. It is submitted, however, that causation should be exercised in seeking to rely on decision concerned with claims for compensation, when considering the imposition of criminal liability.

To date, the only significant attempt to reconcile Blaue and Roberts is the

\footnotetext{
${ }^{30}(1982) 1$ WLR 425.

${ }^{31}$ (1986) 83 Cr App P 23.

${ }^{32}$ (1989) CrimLR 149.

${ }^{33}$ (2002) CrimLR 490.

${ }^{34}(1957) 2$ All ER 807.
} 
Court of Appeal's decision in $R v$ Williams $^{35}$, where $\mathrm{D}$ had jumped to his death from a moving car in order to escape from a robbery. Stuart-Smith LJ stated:

"...the nature of the threat is of importance in considering both the foreseeability of harm to the victim from the threat and the question of whether the deceased's conduct was proportionate to the threat; that is to say that it was within the ambit of reasonableness and not so daft as to make his own voluntary act one which amounted to a novus actus interveniens and consequently broke the chain of causation... it should of course be borne in mind that a victim in the agony of a moment do the wrong thing... The jury should bear in mind any particular characteristics of the victim and the fact that in the agony of the moment he may act without thought and deliberation."

The difficulty with the approach is that it simply begs the question: If $\mathrm{V}$ is "daft" and attempts an escape that a sensible person would realize was fool hardy, does V's escape break the chain of causation, or does D have to take his victim as he finds him?

\subsubsection{Novus Actus Interveniens: The Acts of a Third Party}

The principle of reasonable foreseeability is equally applicable to those situations where the intervention of a third party is a factor in causing the death of V. For example, in Haystead $v D P P^{36}$, the Court of Appeal observed that there had been no novus actus where $\mathrm{D}$ had assaulted $\mathrm{W}$ causing her to drop the baby she was holding, the baby sustaining an injury on hitting the ground. The action of dropping the baby was not seen as "voluntary" in so far as it was a natural response to what $\mathrm{D}$ had done to $\mathrm{W}$.

\section{Case Studies}

In $R v_{\text {Paget }}{ }^{7}, \mathrm{D}$ had armed himself with a short gun and taken a $\mathrm{V}$, a pregnant girl, hostage in a block of flats. The police besieged the building, calling on him to come out, which he eventually did, holding $\mathrm{V}$ in front of him as a human shield. D fired the shot-gun at the police officers who returned fire, striking and killing V. D was convicted of manslaughter, the conviction being upheld by the Court of Appeal which held that the reasonable actions of a third party, by way of self-defence, could not be regarded as a novus actus interveniens. In this case the police officers had instinctively returns D's fire; the need for them to act in self-defence had been caused by D's firing of his own gun, and their actions were reasonable in the circumstances. As Robert Goff LJ observed:

"There can, we consider, be no doubt that a reasonable act performed for the purpose of self-preservation, being of course itself an act caused by the accused's own act, does not operate as a novus actus interveniens... for present purposes, we can see no distinction in principle between an attempt to escape the consequences of the accused's act, and a response which takes the form of self-defence against the act of the accused causes the death of a third party, we can see no

\footnotetext{
${ }^{35}$ (1992) 1 WLR 380.

${ }^{36}(2000) 3$ All ER 890.

${ }^{37}$ (1983) 76 Cr App R 279.
} 
reason in principle why the act of self-defence, being an involuntary act caused by the act of the accused, should relieve the accused from criminal responsibility fort the death of the third party."

As he further observed:

“... simply that in law the accused's act need not be the soul cause, or even the main cause, of the victim's death, it being enough that his act contributed significantly to that result."

In $R$ vShohid and Another ${ }^{38}$, the $\mathrm{D}$ was one of a number of people congregating together at the foot of a flight of stairs at a railway station. The victim was attacked by the $\mathrm{D}$ and other members of this group when he descended the stairs to the platform. As a result of this attack the victim fell onto the railway track and approximately 25 seconds later was hit by a train and fatally injured. The appellant was convicted of manslaughter and appealed on the basis that other members of the group had prevented the victim from climbing back from the track onto the platform, and that this amounted to a break in the chain of causation in law such that the appellant's actions could not be regarded as the cause of death.

The appeal was dismissed. It was not necessary for the prosecution to show that the appellant's actions were the sole or major cause of death. The trial judge had correctly directed the jury to the effect that the evidence of fighting and the threatening of the victim could constitute an unlawful and dangerous act that amounted to a cause of death. There was no requirement that the appellant had foreseen the consequences of his unlawful and dangerous act i.e. that others might prevent the victim from climbing back onto the platform (Smith \& Hogan, 2006).

In policy terms the decision seems to accord with common sense. If the appellant had not attacked the victim he would not have fallen onto the track. To contend that the unlawful actions of another party prevented the victim from escaping the peril created by the appellant is not an attractive argument. There is no discussion in the report of the legal basis for rejection the novus actus interveniens argument. It could have been argued that the actions of others in refusing to allow the victim to escape from the oncoming train were unforeseeable.

\subsubsection{Novus Actus Interveniens: The Acts of a Third Party-Medical Treatment}

In what circumstances can the medical treatment received by $\mathrm{V}$, following an attack by $\mathrm{D}$, relieve $\mathrm{D}$ of liability for homicide if $\mathrm{V}$ subsequently dies? Perhaps a simple and logical response would be to contend that whilst it is reasonably foreseeable that the victim of an attack will require medical attention, the chain of causation should be broken if that medical attention is unforeseeably poor incompetent. As will be seen, however, there are broader policy considerations to take into account. Now the court could consider the following issues:

${ }^{38}$ (2003) All ER (D) 216 (Dec). 
- Firstly, the D's liability may depend upon the quality of health care available to $\mathrm{V}$;

- Secondly, the extent to which the courts may take into account the pressures under which doctors providing public health care have to operate.

\section{Case studies}

A useful starting point can be the Court of Appeal's decision in $R \mathrm{~V} \mathrm{Jordan}{ }^{39}$. $\mathrm{D}$ had stabbed $\mathrm{V}$, who was admitted to hospital, where he died. D was convicted of murder, but appealed when new evidence came to light that, whilst in hospital, V had been given a drug to which he was allergic. The conviction was quashed on the ground that the medical treatment had been "palpably wrong"; with the result that it broke the chain of causation between the stabbing and the death.

As Harrett J. observed;

"... we are disposed to accept it as the law that death resulting from any normal treatment employed to deal with a felonious injury may be regarded as caused by the felonious injury, but we do not think it necessary to examine the cases in details or to formulate for the assistance of those who have to deal with such matters in the future the correct test which ought to be laid down wit regard to what is necessary to be proved in order to establish casual connection between the death and felonious injury. Not only one feature, but two separate and independent features, of treatment were, in the option of the doctors, probably wrong and these produce the symptoms discovered at the post mortem examination which were the direct and immediate cause of death, namely, the pneumonia from the conditions of oedema which was found."

Whilst Jordan clearly establishes that wrongful medical treatment can constitute a novus actus, subsequent decisions confirm that it is, to some extent, a decision that rests upon its own peculiar facts, and, more generally, that the courts are reluctant, as a matter of policy, to permit $\mathrm{D}$ to escape liability on the basis of $\mathrm{V}$ receiving inadequate treatment.

In $R v_{S m i t h}{ }^{40}$, D had been involved in a fight with $\mathrm{V}$, a fellow soldier, during the course of which he had stabbed $V$ several times with a bayonet, which results in $\mathrm{V}$ being taken to a medical post where he had died approximately one hour later. On being convicted of murder D contend that the chain of causation between the stabbing and the death had been broken by the way in which $\mathrm{V}$ had been treated, in particular the fact that he had been handled roughly whilst being carried to the medical post, and that there had been a delay in providing $\mathrm{V}$ with treatment because of the number of the other cases being dealt with. Upholding the conviction, Lord Parker CJ observed:

"...only if it can be said that the original wounding is merely the setting in which another cause operates can it be said that the death did not result from the wound."

${ }^{39}(1956) 40$ Cr App R 152.

${ }^{40}(1959) 2$ QB 35. 
The emphasis on the original wound inflicted by $\mathrm{D}$ as the cause of death also underpins the approach of the courts in those cases where doctors have decided to withdraw treatment from the victim of an assault, with the result that the victim dies.

In $R$ vMalcherek, $R v_{\text {Stee }}{ }^{11}$, both defendants had, in separate incidents, attacked women, causing injuries that were so severe that their victims had to be placed on life support machines in hospital. In both cases doctors decided to stop the life support machine after determining that the victim were "brain dead" and there was n prospect of recovery. Both defendants were convicted of murder. The common ground of appeal in both cases was that the doctors had broken the chain of causation between the defendants' attack and the deaths of the victims by deliberately switching off the life support machines. The Court of Appeal, by dismissing the appeals, held that in both cases the operating and substantial cause of deaths had been the original wounds inflicted by the defendants. On a broader policy basis, the lord Chief Justice expressed the view that nothing done by a doctor in the ordinary course of medical treatment could be regarded as a novus actus interveniens. It should not be assumed from this, however, that bona fide medical interveniens could never form the basis of criminal liability.

In $\operatorname{Re} A$ (Children) (above), Ward LJ rejected the "sweeping statement" that bona fide medical or surgical treatment was never "unlawful". As he observed:

"Whether immunity doctors do enjoy, they have no complete immunity."

It is tempting in the light of the above, to talk in terms of medical treatment breaking the chain of causation only if it is reckless or grossly negligent, suggesting perhaps that liability for the death is there by transferred to the medical practitioners treating the victim. The court of appeal's decision in $R_{V}$ Cheshire $^{42}$, however, suggest that a clear distinction should be maintained between the actions of medical practitioners, which may break the chain of causation, and the state of mind that accompanies such actions. Beldam LJ noted that:

"Even though negligence in the treatment of the victim was the immediate cause of his death, the jury should not regard it as excluding the responsibility of the accused unless the negligent treatment was so independent of his acts, and in itself so potent in causing death, that they regard the contribution made by his acts insignificant....[E] ven if more experienced doctors than those who attend the deceased would have recognised the rare complication in time to have prevented the deceased's death, that complication was a direct consequence of the appellant's acts which remained a significant cause of his death."

In the recent cases of $R{ }_{V}$ Warburton and Hubberstry ${ }^{43}$ and $R{ }_{V}$ Flaherty $^{44}$ the courts have considered the above principle. The case for jury in relation to causation was simple, namely, whether the acts for which the $\mathrm{D}$ was responsible significantly contribute to V's death.

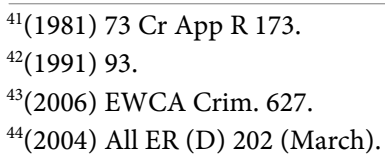


The Law commission, A Criminal code for England and Wales commented that, "the principle [of causation] to be found in the common law....are reasonably well settled and can be stated quite shortly." (Storey, 2004). In "Textbook of Criminal law", G. Williams states, "hitherto the judges have made little progress in establishing [the] principle [of imputation]". Alan Norrie ${ }^{46}$ accepts that Williams' assessment of the position is much closer to the mark than that of the law commission. In Recent Law Commission Consultation Paper ${ }^{47}$ the principle of causation was not considered (Norrie, 1991).

\section{Mens Rea of Murder}

\subsection{The Mental Element of Murder: Malice Afore-Thought}

Over the last fifty years the fault element of murder has caused the courts great difficulties ${ }^{48}$. Murder is unlawful homicide committed with "malice aforethought". This general definition is now useless; neither malice ${ }^{49}$ nor aforethought $t^{50}$ is necessary, or sufficient enough for a finding of murder (Norrie, 1999; Dennis, 1988). It should be noted here that "Malice afore thought" has been a technical term which describes the mens rea required by the common law for a conviction of murder. Before 1957, three kinds of malice afore thought were present-"express", "implied" and "constructive". An intention to cause death was required for expressed malice. Implied malice required a proof of an intention to cause grievous bodily harm. The result of constructive malice was that if D killed in the course of committing a felony, such as burglary, he would be charged with murder, because the necessary mens rea would be construed from his having committed the felony. This rule operated in a spectacularly harsh fashion. D could be charged with P's murder, even though he might actually intend neither to kill nor to cause grievous bodily harm. The1957 Act abolished constructive malice but did not replace it with a statutory definition of murder. So, after the 1957 Act implied as well as express malice survives.

\subsection{Intend to Cause Grievous Bodily Harm (Implied Malice)}

An intention to cause grievous bodily harm remains sufficient mens rea for murder after surviving several attempts to unseat it. This aspect of the mensrea has been subject to considerable academic and judicial criticism ${ }^{51}$.

\section{Case Studies}

In Vickers ${ }^{52}$, D had been convicted of murder on the basis that he intended to

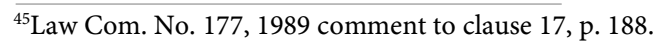

${ }^{46}$ School of law, University of Warwick, UK.

${ }^{47}$ A New Homicide Act for England and Wales? (2005).

${ }^{48}$ See Law Commission Report (2005).

${ }^{49} \mathrm{It}$ is murder, for example, if D's intentional killing of $\mathrm{V}$ is done from motives of compassion, say because $\mathrm{V}$ has a painful, terminal illness.

${ }^{50} \mathrm{~A}$ spontaneous intentional killing is murder in the absence of any justification, excuse, or extenuation.

${ }^{51}$ See Lord Steyn's speech in Powell and Daniels English (1999) 1 AC 1.

${ }^{52}(1957) 2$ QB 664.
} 
cause grievous bodily harm. On behalf of $\mathrm{D}$ it was argued that, this appeared to overlap with constructive malice as causing grievous bodily harm was a felony. The argument was rejected by the Court of Criminal Appeal ${ }^{53}$ (Williams, 1983).

In the case of Hyam ${ } D P P^{54}$ a majority of their Lordship extended the mens rea somewhat further by holding that it was sufficient for $\mathrm{D}$ to have foreseen that death or grievous bodily harm was a probable, or highly probable, consequence of his actions. This "heretical" confusion of foresight with mens rea was compounded in the subsequent House of Lords decision in $R_{V}$ Cunningham $^{55}$. Here, the House of Lords decided finally that intent to cause grievous bodily harm was implied malice, so constitutes sufficient mens rea for murder and was something separates from constructive malice. What precisely it conveyed was a matter of intense criticism at the highest judicial level as this decision allowed convictions for murder without proof of any culpability element. Lord Mustill ${ }^{56}$ describes the decision a "fiction". The criticism has particular force in circumstances where the harm in question, although "really serious", is not harm which constitutes, of itself, a threat to life. As Lord Edmund-Davies observed in his dissenting speech in Cunningham, a broken arm is "really serious" ${ }^{157}$ but an intent to inflict such an injury should be regarded as insufficient for most serious of crimes $^{58}$ (Duff, 1990). Despite the continuing vein of judicial criticism $^{59}$, the law is settled by Cunningham and any further change will require legislation (Simester \& Sullivan, 2004).

\subsection{Intent Is Subjective}

The intent required for murder is an intent that the accused himself must be proved to have possessed. Such a statement of the obvious needs to be made, however, because of the notorious decision of the House of Lords in DPP $V$ Smith ${ }^{60}$.

\section{Case Studies}

According to Smith (above), a person may be convicted of murder even though he did not intend to kill nor even foresee death as a possibility. This case allowed a conviction of murder on the basis of negligence, on the foresight of the reasonable person rather than the accused. The House of Lords decision in question has aroused controversy and has been a subject of intense debate ${ }^{61}$ (Dennis,

\footnotetext{
53“To kill by causing grievous bodily harm was not to cause death by an offence separate from the killing. The infliction of bodily harm was the direct cause of death."

${ }^{54}(1975)$ AC 55.

${ }^{55}(1982)$ AC 566.

${ }^{56}$ A-G's Reference (No 3 of 1994) [1998] AC 245, 262.

${ }^{57}$ The interpretation of grievous bodily harm given in DPP v Smith (1961) AC 290, 334.

${ }^{58}$ (1982) AC 566, 582-3.

${ }^{59}$ Powell, Daniels and English (1999) 1 AC 1, 11 (Lord Mustill), 14-15 (Lord Steyn); Woollin (1999) AC 82, 90 (Lord Steyn).

${ }^{60}(1961)$ AC 290.

${ }^{61}$ Contrast Denning, Responsibility before the Law (1961) with Williams, 'The Mental Element in Crime' (1965), chap. 1.
} 
1988). As a consequence the Law Commission recommended a two-clause bill ${ }^{62}$ to change the law (Geoff, 1988). While the clause that focused directly on the decision in Smith was dropped; another clause, that was enacted, subsequently became Section 8 of the Criminal Justice Act 1967. Section 8 does not say anything on the definition of proof of Intent and foresight, or about when intent or foresight need be proved. Rather, the section has application only when the definition of an offence requires proof of intent or foresight on the part of D. After Section 8 came into force, Smith was regarded as overturned ${ }^{63}$ by appellate court.

Moreover, the Privy Council in Frankland ${ }^{64}$ advised that Smith had been based on a misunderstanding of the common law and should no longer be followed in a common law jurisdiction, which did not possess the equivalent of Section 8.

\subsection{The Meaning of Intent in Murder}

It is presumable that D intends to cause V's death or grievous bodily harm, if D acts in order to cause death or grievous bodily harm to $\mathrm{V}$ or if he causes death or grievous bodily harm as a necessary means to some other end. In such cases Lord Bridge's “Golden Rule” applies ${ }^{65}$ (Lacey, 1993). This approach is commendably straightforward. Where $\mathrm{V}$ has died following an attack by $\mathrm{D}$ with a gun, a very strong inference arises that $D$ attacked in order to kill or seriously hurt V. The jury may be safely left to draw that inference in the absence of any reason why they should not do so (Simester, 2002).

Such an uncomplicated approach is impossible where there is no compelling evidence that $\mathrm{D}$ intended to cause kill or grievous bodily harm in this core sense. In Simester and Sullivan's useful example ${ }^{66}$ : D sets fire to a house in order to make a fraudulent insurance claim in respect of the damage he will cause. He is aware that the house is occupied by $\mathrm{V}$ and that it is virtually certain that $\mathrm{V}$ will perish in the fire. Here there may be no evidence that $\mathrm{D}$ intends the death of $\mathrm{V}$ in the core sense of that term. He may be wholly indifferent whether $\mathrm{V}$ lives or dies. The existence or non-existence of $v$ may have no bearing whatever on the success of his fraudulent claim. Consequently, were D to be charged with murder of $v$, this would be one of those "rare cases" where a direction on intention of the kind laid down by the House of Lords in Woollin would be required ${ }^{67}$ (Nor-

\footnotetext{
${ }^{62}$ Clause 54 provides: “(1) A person is guilty of murder if he causes the death of another-(a)intending to cause death: or (b) intending to cause serious personal harm and being aware that he may cause death..."

${ }^{63}$ Wallett (1968) 2 QB 367.

${ }^{64}$ (1987) AC 576.

${ }^{65}$ Moloney (1985) AC 905,926 "When directing a jury on the mental element necessary in a crime of specific intent, the judge should avoid any elaboration or paraphrase of what is meant by intent and leave it to the jury's good sense to decide whether the accused acted with the necessary intent...” ${ }^{66}$ Ibid.

${ }^{67}$ (1999) AC 82, 90, "the jury should be directed that they are not entitled to find the necessary intention, unless they feel sure that death or serious injury was a virtual certainty (barring some unforeseen intervention) as a result of the defendant's actions and that the defendant appreciated that such was the case."
} 
rie, 1999).

So, in simple word, Woollin establishes that foresight of virtual certainty is the basis of finding intention in the secondary, non-core sense. It is to be hoped that Woollin further establishes that proof of foresight on the part of $\mathrm{D}$ that it is virtually certain $\mathrm{D}$ will cause death (or grievous bodily harm) to $\mathrm{V}$ constitutes intent, in the secondary non-core sense, to cause death (or grievous bodily harm) (Simester, 1999). It is when we lack evidence of intent in the core sense that a Woollin is required. To conclude, we could say that if a jury seeks guidance on the right approach to intent in a murder trial, it should be made clear to them that they are entitled to find that D intended to kill or do grievous bodily harm as a virtually certain consequence of his action.

Writing in the page of the Criminal Law Review, Professor Sir John Smith describes the House of Lords judgment of Woollin as "important and most welcome" for drawing a "firm line" ${ }^{168}$ between intention and recklessness. But the House of Lords decision in Woollin has been gone through several criticisms that it does not constitute the last word on indirect intention for murder.

According to William Wilson" ${ }^{69}$, "the present meaning of intention is still generally unstable and that the decision renders the board doctrinal terrain of homicide less intelligible" (Wilson, 1990; Wilson, 1999). In the word of Alan Norrie $^{70}$, "I argue that the law of indirect intention may still remain unclear after the recent House of Lords decision in Woollin. The cognitivism of the law of intention cannot reflect the broader moral issues, yet they remain central to the judgment of criminal culpability."However, as doctrinal ambiguity decreases so mounts the tension between different parts of the structure of criminal liability and so also increases the pressure for such a development. In this light, Woollin is a small, if equivocal, step in the right direction (Norrie, 1989; Norrie, 1990).

\section{Findings}

As can be seen from the above discussions, the offence of common law murder is an extremely complicated area. It is a judicial description of the offence dating from the seventeenth century. Over the century the law of homicide, including the law of murder has developed in a higgledy-piggledy fashion. The outcome is a body of law characterized by lack of clarity and coherence. It does not represent what parliament understood and intended the law to be when it last took a detailed look at the law of murder and enacted the Homicide Act 1957. The 1957 Act had been preceded by the report of the Royal Commission on Capital Punishment 1949-1953. In evidence to the Commission, the Lord Chief Justice said that the law of England and Wales was that persons were not guilty of murder merely because they intended to cause serious harm. Persons intending to cause serious harm also had to know that they were endangering life. No long after the 1957 Act was passed; a decision of the Court of Criminal Appeal ${ }^{68}$ (1998) Crim. L.R. 890 at 891.

${ }^{69}$ Law Department, Brunel University.

${ }^{70}$ School of Law, Kings College London, UK. 
proved Parliament's understanding of the law to have been wrong. The court, presided over by the Lord Chief Justice, held that the law of England and Wales had always been that persons, who intended to cause serious harm, without realizing that they were endangering life, were guilty of murder if the victim died. That continues to be the law. The Law Commission Consultation Paper " $A$ New Homicide Act for England and Wales?” (2005) has provisionally proposed for grading and labeling homicide offences as the commission has figure out that the fundamental weakness of this law is that different levels of criminality are not accurately graded and rebelled. There are three factors that can influence the way that offences are graded:

1) Fault element ${ }^{71}$;

2) Aggravating factors;

3) Mitigating factors.

Current law places particular emphasis on the fault element.

\section{Conclusion}

According to this article, first-degree murder is confined to killing committed with an intention to kill and the punishment would be mandatory life sentence. Second-degree murder encompasses unlawful killing where the offender's intention was to cause serious harm. The evolution of the two concepts: actus reus and mens rea, has been slow and cumbersome. Leading to accusation that the only reason for this is that the subject is too emotive. Although the definition is now more settled than ever before, this area of the homicide offences is crying out for an outline drawn up by statute, similar to that provided for in the United States. Although elements of the offences have been modified by a number of Acts of Parliament the definition of the murder is still to be found at common law; therefore, further researches are strongly recommended in this area of law.

\section{Conflicts of Interest}

The authors declare no conflicts of interest regarding the publication of this paper.

\section{References}

Allen, Elliott, \& Wood (2001). Cases and Materials on Criminal Law (8th ed.). Sweet and Maxwell.

Ashworth, A. (2006). Principle of Criminal Law. Oxford University Press.

Card, R. (2006). Cross Jones and Card: Introduction to Criminal Law (17th ed.). Oxford University Press.

Clarkson, C. M. V. (2005). Understanding Criminal Law (4th ed.). Sweet and Maxwell.

Clarkson, C. M. V., \& Keating, H. M. (2003) Criminal Law: Text and Materials (5th ed.). Sweet and Maxwell.

Dennis (1988). Intention and Complicity: A Reply. Crim LR 649.

${ }^{71}$ Offender's state of mind at the time of committing of the offence. 
Douglas, G. (2005). Criminal Law (4th ed.). Oxford University Press.

Duff (1990). The Politics of Intention: A Response to Norrie. Crim LR 637.

Duff, R. A., \& Green, S. P. (2005). Defining Crimes: Essay on the Special Part of the Criminal Law. Oxford University Press.

Emmerson, B., \& Ashworth, A. (2012). Human Rights and Criminal Justice (paras 18.30-18.34). Sweet \& Maxwell.

Geoff, L. (1988). The Mental Element in the Crime of Murder. 104 LQR 30.

Herring, J. (2007). Criminal Law (5th ed.). Basinstroke: Palgrave Macmillan.

Holland, J. A., \& Webb, J. S. (2006). Learning Legal Rules (6th ed.). Oxford University Press.

Keenan, D. J. (2007). Smith's and Keenan's English Law: Text and Cases (15th ed.). Longman.

Lacey, N. (1993). A Clear Concept of Intention: Elusive or Illusory. 56 MLR 621-3.

Martin, J. (2006). Criminal Law. Hodder Arnold.

Molan, T. M. (2007). 150 Leading Cases. Old Bailey Press.

Norrie (1989). Oblique Intent and Legal Politics. Crim LR 793.

Norrie (1990). Intention: More Loose Talk. Crim LR 642.

Norrie (1991). A Critique of Criminal Causation. 54 MLR 685.

Norrie (1999). After Woollin. Crim LR 532.

Roe, D. (2005). Criminal Law. Hodder Arnold.

Simester (1999). Murder, Mens Rea and the House of Lords-Again. 115 LQR 17.

Simester, A. P. (2002). Principle on Criminal Law (2nd ed.).

Simester, A. P., \& Sullivan, G. R. (2004) Criminal Law: Theory and Doctrine (2nd ed.). Hart Publishing.

Smith, J. C., \& Hogan, B. (2006). Criminal Law: Cases and Materials (9th ed.). Oxford: Oxford University Press.

Storey, T. (2004). Criminal Law (3rd ed.). Cullompton: Willian.

Williams, G. (1983). Text Book of Criminal Law(2nd ed.).

Wilson (1990). A Plea for Rationality in the Crime of Murder. 10 LS 307.

Wilson (1999). Doctrine Rationality after Woollin. 62 MLR 448. 